\title{
LANDSLIDE SUSCEPTIBILITY ASSESSMENT THROUGH FUZZY LOGIC INFERENCE SYSTEM (FLIS)
}

\author{
T. Bibi *, Y.Gul, A. Abdul Rahman, M.Riaz \\ ${ }^{a}$ Department of Geoinformation, Faculty of Geoinformation and Real Estate, Universiti Teknologi Malaysia, Skudai \\ 81310, Johor, Malaysia - tehmina_khan79pk@hotmail.com, yasmeengul9@gmail.com, alias.fksg@gmail.com \\ ${ }^{\mathrm{b}}$ National centre of excellence in Geology, University of Peshawar, Pakistan - mriaz@upesh.edu.pk
}

KEY WORDS: Landslide, GIS, Susceptibility, Fuzzy logic, Pakistan.

\begin{abstract}
:
Landslide is among one of the most important natural hazards that lead to modification of the environment. It is a regular feature of a rapidly growing district Mansehra, Pakistan. This caused extensive loss of life and property in the district located at the foothills of Himalaya. Keeping in view the situation it is concluded that besides structural approaches the non-structural approaches such as hazard and risk assessment maps are effective tools to reduce the intensity of damage. A landslide susceptibility map is base for engineering geologists and geomorphologists. However, it is not easy to produce a reliable susceptibility map due to complex nature of landslides. Since 1980s, several mathematical models have been developed to map landslide susceptibility and hazard. Among various models this paper is discussing the effectiveness of fuzzy logic approach for landslide susceptibility mapping in District Mansehra, Pakistan. The factor maps were modified as landslide susceptibility and fuzzy membership functions were assessed for each class. Likelihood ratios are obtained for each class of contributing factors by considering the expert opinion. The fuzzy operators are applied to generate landslide susceptibility maps. According to this map, $17 \%$ of the study area is classified as high susceptibility, $32 \%$ as moderate susceptibility, $51 \%$ as low susceptibility and areas. From the results it is found that the fuzzy model can integrate effectively with various spatial data for landslide hazard mapping, suggestions in this study are hope to be helpful to improve the applications including interpretation, and integration phases in order to obtain an accurate decision supporting layer.
\end{abstract}

\section{INTRODUCTION}

Now days the science and technology is on its peak of progress even then the natural phenomenon's are significantly affecting the socioeconomic conditions around the globe. Natural events (e.g. earthquakes, landslides, floods, storms etc.) are commonly known as natural hazards. The world is threatened by a rapidly growing impact of natural hazards, which alternately cause an increase in the vulnerability to society as well as in hazardous events. Natural disasters increased more than three times and the economic losses increased more than eight-fold since 1960's (Melching and Pilon, 2006). Every year several deaths have been recorded due to natural disasters around the world especially in developing countries (Huppert and Sparks, 2006). The probability of occurrence and relative frequency of hazardous events are the main characteristics of a disaster base on which its level of risk can be calculated. On the other hand the impact is dependent on intensity or magnitude of the events. The monitoring of the natural hazards includes the evaluation of their impact and risk assessment. It is an important step for decision making towards the selection of possible protective measures (Zlateva et al. 2011).

As many part of the world, in Pakistan, due to its physical and climatic characteristics, landslides are the regular events responsible for critical casualties and economic losses. Especially, Northern areas of Pakistan which are prone to severe landslide because of young Himalayas and throughout active fault zones. That is why landslide susceptibility and hazard assessment for regional scale gets importance in recent years. Hazard mapping, includes the spatial and temporal probability of landslide occurrence for a region. However it is very difficult in Pakistan due to non-availability of landslide records and necessary information. As a result of this situation, risk mapping of landslide is actually difficult. Hence, landslide susceptibility mapping is a common approach to be developed in the evaluation of landslide prone areas.

In the southeast Asia, Indian sub-continent, Pakistan is a country (covering 770,998 Km2 with 192 million inhabitants) exposed to many severe natural hazards, such as earthquakes, floods, landslides, snow avalanches, storm surge and wind storms . Northern Pakistan have the most expressed tectonic and seismotectonic activity on the whole territory of the country. The existence of active faults is the significant feature of the region due to young Himalayans. Besides with the seismic activity, many other natural hazards (flood, landslide, snow avalanches etc.) provoke the activation of gravitational processes. Northern Pakistan is a region where an international transport corridor (Silk rout), connecting china with Pakistan to promote Pak-China trade, is also known as China Pakistan Economic Corridor (CPEC). A collection of projects are currently under construction (around $\$ 46$ billion) with the intent to expand and upgrade Pakistan's infrastructure, as well as strengthen the economic links between Pakistan and China. This route is extremely important for both countries and is a part of the national critical infrastructure.

Landslide susceptibility assessment approach is meant to estimating the probability of landslide occurrence considering the correlations between terrain and the past landslide distribution (Vahidnia et al., 2010). The term "susceptibility" refers to the likelihood of landslide occurrence when leaving triggering variables out of assessment (Dai et al., 2002). In last few decades, it has become a significant subject for planners, 
engineers, earth scientists and decision makers (Ercanoğlu and Gökçeoğlu, 2002). Landslide is one of the most complex phenomena and due to its complex nature several qualitative and quantitative methods have been applied for the assessment of landslide susceptibility and risk. All these method owns its advantages and disadvantages. But mainly it depends on the objective of the study, scale and data availability. Susceptibility assessment system plays an important role in risk assessment to attain faster decisions and reduce human errors (Shang and Hossen, 2013). The overall process of susceptibility assessment includes understanding the sources, areas of impact, events and their causes and potential consequences (Gjerdrum and Peter, 2011).

Landslide is one of the most complex phenomena and due to its complex nature several qualitative and quantitative methods have been applied for the assessment of landslide susceptibility and risk. Each method possesses its advantages and disadvantages. The choice of a method depends on the objective of the study, scale and data availability. Susceptibility assessment system plays an important role in risk assessment to attain faster decisions and reduce human errors (Shang and Hossen, 2013). The overall process of susceptibility assessment includes understanding the sources, areas of impact, events and their causes and potential consequences (Gjerdrum and Peter, 2011).

A number of surface based 2D representations/ data structures have been introduced to design 2D surface model. For example Grid, Quad tree, Triangular Irregular Network (TIN). TIN data structure is the widely used 2D data structure in terrain modelling. Hence, working with this data structure Peucker et al(1978), and Peuquet(1990) noticed that all measured data was used directly since these data form triangle's nodes. Then, nodes used to construct any DTM products after interpolation e.g. contour, slope, aspect etc. The network of triangles suggests a relatively easy way of integrate drainage lines, breaklines, and faultlines thus tailored to the terrain variations. TIN data structure is based on Delaunay algorithm which can deal at the same time with discrete objects and continuous phenomena (field), and have an interactive topological network for mathematical modelling. Several methods are used to store TIN data structure e.g. triangle-by-triangle, points and the neighbours, and side-based etc. Terrain characteristics are very important for assessment of landslide susceptibility. Slope is most relevant and important terrain condition. TIN data structure is used to get the terrain information in landslide susceptibility assessment.

Fuzzy logic methods have been developed in susceptibility and risk assessment for a decade (Karimpour et al., 2016). These models are built upon fuzzy set theory and fuzzy logic. This is among one of the heuristic approaches which is used for vulnerability and susceptibility and risk assessment worldwide in all disciplines (Vahidnia et al., 2010; Ercanoğlu and Temiz, 2011; Gorsevksi et al., 2006; Pradhan, 2010; Tangestani, 2009). It is a step to systematize two remarkable human abilities, first, the ability to converse, reason and make coherent decisions in an environment of inadequate information; it can analyse risks with insufficient knowledge or vague data. And second, to perform a wide range of mental and physical tasks without any measurements and any computations (Zadeh, 2008; Pokorádi., 2009; Zlateva et al. 2005).

Fuzzy models explicitly consider the cause-and-effect chain among variables. Most variables are described in linguistic a term, which makes fuzzy, models more intuitively similar to human reasoning. Mumdani fuzzy model is widely using to assess the susceptibility of natural hazards. It has been used to assess the susceptibility and risk of landslides (Pourghasemi et al., 2012; Akgün et al., 2012; Osna et al., 2014; Eker and Aydın, 2014), flood risk assessment (Yazdi and salehi., 2012; Beaula and Partheeban., 2013). The ability to handle nonlinearity and interpretability are the main feature of this models (Jang, 1993). It can be created by translating knowledge of experts to linguistic information as fuzzy rules, though there is no standard method available for transmuting expert's knowledge (Yanar and Akyürek, 2006). Fuzzy logic susceptibility assessment expresses the possibility of an outcome. The input and output relationships in fuzzy susceptibility assessment are determined by sets of logical rules (Blair et al., 2001). Fuzzy logic susceptibility assessment can be used for cases with vague, imprecise and insufficient input data (Darbra and Casal, 2009). The output or results of susceptibility assessment by fuzzy logic are easy to understand for decision-making. In fact, managers can understand results and outgoings better and more precisely.

The aim of this paper is to propose a fuzzy logic model for landslide susceptibility assessment in District Mansehra of Pakistan using the available information and the expert knowledge. The model is designed in the Matlab software with five input and one output environment. The obtained results can support the natural risk management.

\section{MATERIALS AND METHODS}

\subsection{Study Area}

The study area is located at the north eastern border of the Pukhtun Khawa province of Pakistan between $34^{\circ}-12^{\prime}$ to $35^{\circ}$ $50^{\prime} \mathrm{N}$ latitude and $47^{\circ}-07^{\prime}$ to 74 to $08 \mathrm{E}$ longitudes. Mountain ranges, plains, valleys. Numerous lakes and rivers are some of the main features of the geography of Mansehra. It is bounded on the north by Kohistan and Batagram districts, on the east by Muzaffarabad district, on the south by Abbottabad and Haripur districts and on the west by Shangla and Buner districts. The total area of the district is 4,579 square kilometres. (Fig. 1.2 Geographic map)

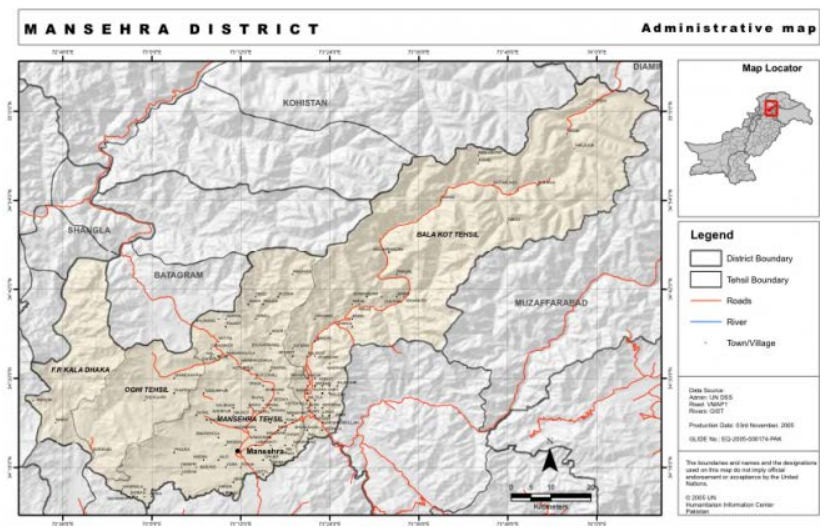

Figure 1. Locational map of Mansehra District. (Source United Nation)

The climate of the district is warm in summer and cold in winter. However, the northeastern part of the district i.e. the Kaghan valley is cold in summer and very cold in winter and receives heavy snowfall on the mountains. The mean maximum 
and minimum temperatures of the district during the month of June are $35^{\circ}$ and $21^{\circ}$ centigrade respectively. January is the coldest month with mean maximum and minimum temperatures of $14^{\circ}$ and $2^{\circ}$ degree centigrade respectively. The rainfall in the area is significant, with precipitation even during the driest month. The average rainfall in the district varies in between $1400 \mathrm{~mm}$ to $1800 \mathrm{~mm}$.

\subsection{Geology and tectonic setting}

Geologically the area is located in Indus-Tsangbo Suture Zone which separates the Indian and Asian plates in eastern Himalaya is bifurcated by the intervening Kohistan island arc into the northern suture (megashear) and southern suture (megashear) in northern Pakistan (Tahirkheli and Jan, 1979). The northern suture is termed the Main Karakorum Thrust (MKT) and the southern suture as Main Mantle Thrust (MMT) by Tahirkheli et al., (1979). The timing of these two sutures is not fully resolved. There is group of geologists who suggest that Kohistan collided with Asia first at about 75 to $95 \mathrm{Ma}$. Still another group of geologist think that Kohistan collided with India first before the terminal collision of India with Asia (Yin and Harrison, 2000; Yin, 2006). Whatever the sequence of accretion was the fact remains that after deformation the deformation propagated southward. As a result, to the immediate south of MMT, the Indian plate crust was imbricated into a number of thrust nappes. Treloar et al., (1989b) recognized at least six thrust nappe structures in the region (Swat, Besham, Hazara, Lower Kaghan, Upper Kaghan and Banna). Each of them is internally imbricated by thrust faults. These nappes are structurally, stratigraphically and lithologically distinct from each other and are individually about 5 to $10 \mathrm{~km}$ thick. These thrusts have higher grade rocks in their hanging wall than in their footwalls. In field, such a configuration results in inverted metamorphic geometry of the suite. Incidentally bulk of these imbricated structure fall within the Mansehra District. It is these nappe structures that are bounded by thrust faults which contribute to the seismicity and other related hazards of the area.

\subsection{Lithology}

Various lithological units exist in the area. Granites cover a large portion (36\%) of the central and northern part of the study area. The main mineral constituents are microline, oligoclase, and quartz, with small amounts of biotite and muscovite and accessory magnetite, apatite, and sphene. As granite is a hard rock having very high strength and is thus very useful from engineering prospective and is highly recommended for strong foundation. Schist is also a wide spread (17\%) lithology of the study area. Schist is mainly fine-grained mica-chlorite-quartz schist. Calcite or graphite, in laminae and disseminated grains, appears in the schist adjacent to layers of marble or graphite schist. Schist is basically metamorphosed rock having complex behavior. It can break along the foliation plains. On higher altitude it can create landslide problems. It is not suitable for mega structures and buildings on high slopes. Quartzite and Metapelite is the dominant part (22\%) of the Tanawal Formation and can be seen in scattered form all over the mapped area. Although the mechanical properties of quartzite and metapelite are quite different, but they are still lumped together because the metapelite are interlayered with quartzite beds and thus making it very difficult to plot them separately. The Quartzite of the study area is highly fractured because of which it pay additional role in slope failure. Alluvium covers the area (8\%) along rivers.

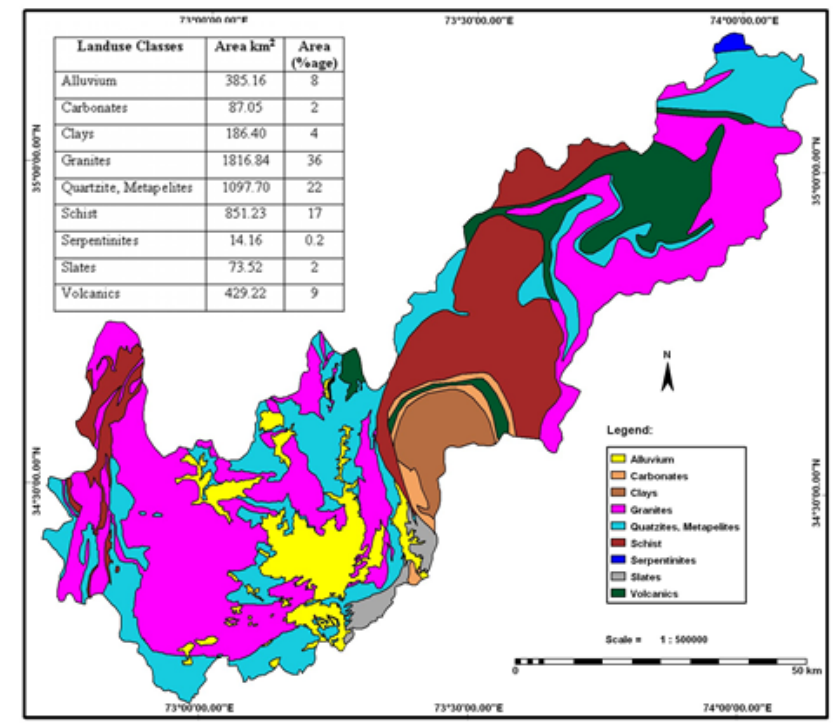

Figure 2. Lithological map of Mansehra District

Alluvium mainly consists of sand, gravel, and boulder deposits brought by streams/rivers. Alluvium is mainly loose surficial material which can be disturbed even by a little shaking. Volcanic include igneous extrusive rocks that have been metamorphosed. These rocks cover the area (9\%) from Naran to Lulusar Lake. These rocks are compact and have more capacity to resist against any natural phenomena. Carbonates (2\%) and Slates (2\%) covers a small portion of the mapped area. Clay is mainly exposing in the marginal areas of Mansehra and Balakot consisting of silt-sized material in cross bedded form. These slates are highly fractured and least stable. Carbonates are also prone to weathering due to its soluble. Clay as classed here is different than alluvium because of its composition. There are very small (4\%) deposits of kaolinitic or more pure clays that do not contain any sand or gravel and thus are distinctly different than alluvium. It has less resistance to excessive water and steep slopes. As the precipitation and slope increases the chances of landslide in clay rich areas increases as well. A very small patch of Granulites and Serpentinites exists in the north of Tehsil. These rocks are fresh, belonging to a granulitic complex very similar to the ones of Chilas (Greco et al, 1989). These are hard rock lithology and more resistive to natural phenomena's.

\subsection{Data}

The study area is one of the most landslide-prone areas of Pakistan, and it has been subjected to a number of landslides. These landslides are generally active deep-seated rotational, and they are usually occur on slopes above rivers and creeks. The occurrence of landslides is mainly controlled by the lithology and slope gradient and rainfall in the area. Surface-water erosion and under- cutting of slopes by both surface water and cliff erosion are also considered as other important landslidecontrolling and triggering factors. Due to the weathering and highly ruptured metamorphosed lithological units in the area, the occurrence of landslide is common, and the presence of faults contributes to the occurrence of landslides.

For landslide susceptibility mapping, a number of thematic data on causative factors were identified. The Mamdani FIS for the assessment of landslide susceptibility for District Mansehra (Northern Pakistan) includes geology, lithology, soil type, slope angle, altitude, precipitation and land use. Topographic maps 
and aerial photographs provided by the Department of Survey, Government of Pakistan were considered as basic data sources for generating some of these layers. On the other hand, field surveys were carried out for the verification of data. These data sources were used to generate various thematic layers using GIS software like ILWIS 3.4, ArcGIS10.0.

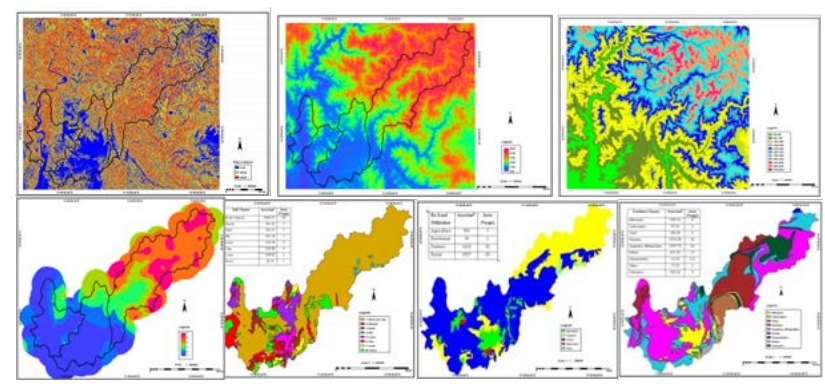

Figure 3. Input data layers

The data was prepared in GIS software (ILWIS and ArcGIS) and assigned with weights according to its resistivity towards slope failer. These maps were converted in to Asci files and then clipping and masking operations were applied in the Matlab. A Fuzzy system was designed to set the input/ output parameters, rules were set according to expert opinion and membership function applied.

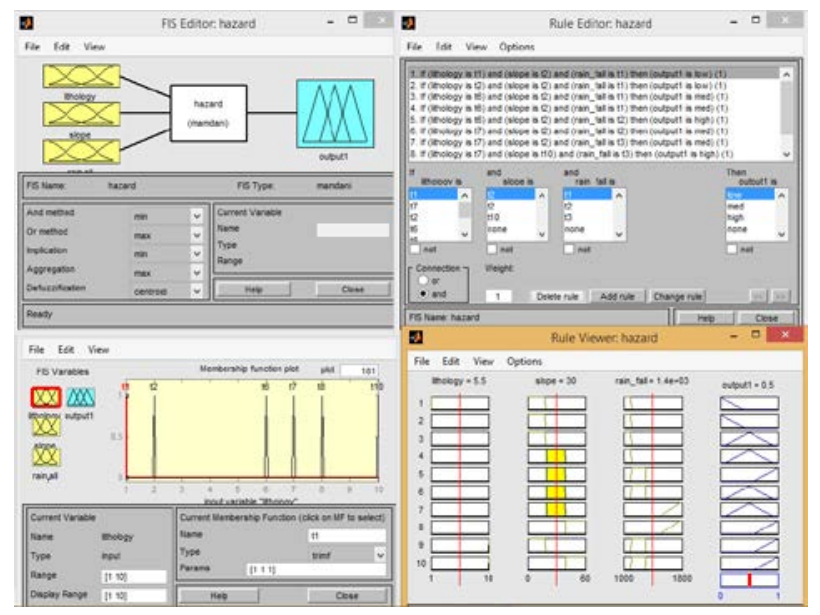

Figure 4.. Mamdani FIS application scheme, followed in this study

It is vital to map the areas which are under high susceptibility of landslides and accordingly a landslide susceptibility map for the study area was prepared. The landslide susceptibility map (Fig 3.7) is divided in to three main zones. Landslides in the study area occur in association with two lithologies (classified as "high"). For this reason, if the rule includes "high" in the lithology input, the output is accepted as "high". The other landslide conditioning factors are considered equally. If three inputs are positive and three inputs are negative for landslide occurrence, the output is assigned as "moderate". If five inputs are positive and three inputs are negative for landslide occurrence, the output is accepted as "low". Morphologically Mansehra district is characterized by high altitude, steep slopes and variable lithology, and is thus highly susceptible to landslide.

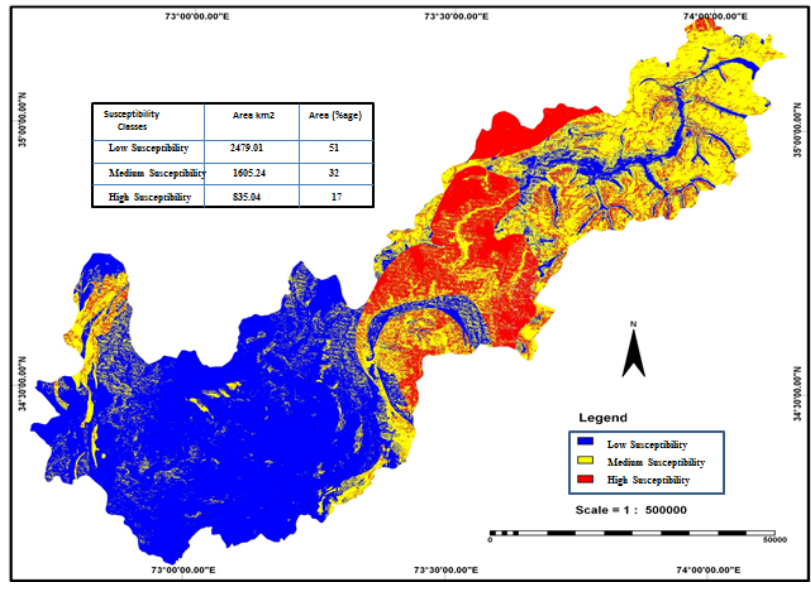

Figure 5. Landslide susceptibility Map

After modeling the Mamdani FIS and producing the susceptibility values the Interface (GUI) was created to see the output in color map. Then, this file was exported into ArcGIS 10.0 software reclassify the output database information. After exporting the data it was converted into a raster file type so it could be classified, and a landslide susceptibility map was obtained (Fig. 9). For visual interpretation of this map, the necessity of classifying data into categorical susceptibility classes arose. The equal interval and standard deviation classifiers was used to classify the map (Ayalew et al., 2005; Akgun et al., 2008).

\section{CONCLUSION}

Landslide is one of devastating natural hazard which sometimes occur with a lot of destruction in the Northern areas of Pakistan. Therefore, the non-structural approaches such as susceptibility and hazard maps are effective tools to reduce the intensity of damage. Natural hazards are nonlinear phenomena and always characterized by insufficient and ambiguous data. Until now several approaches are used to assess the landslides but all these approaches are data driven. But FLIS is an expert based approach and one of the suitable procedures to assess the natural hazard because it has a considerable capacity to model complex and nonlinear systems.

The choice of FLIS allows one to utilize all, the qualitative and quantitative or semi quantitative inputs according to the objectives and scope of the study. The result shows that the low susceptibility areas are around $51 \%$ of area while $17 \%$ of the area is under high susceptibility and $32 \%$ of the area is under moderate susceptibility.

According to Landslide susceptibility map, most of the residential area fall in high susceptible zone, and dense forest areas are under moderate susceptibility which is an indication of human role in the emergence of disaster. This is very important planners and engineers to use the results of such studies for mitigating the hazard by choosing suitable locations to carry out expansions. To avoid the risks of landslide in the study area, it is suggested to have a check on degradation and variation in natural vegetation cover. 


\section{REFERENCES}

Akgun, A., and Bulut, F. (2008). Landslide susceptibility mapping for a landslide-prone area (Findikli, NE of Turkey) by likelihood frequency ratio and weighted linear combination models. Environ Geol 54(6):1127-1143

Akgün, A., Sezer, E.A., Nefeslioğlu, H.A., and Pradhan, B. (2012). An easy to use MATLAB program (MamLand) for the assessment of landslide susceptibility using Mamdani fuzzy algorithm. Computer and Geosciences 38(1): 23-34, doi:10.1016/j. cageo.2011.04.012.

Ayalew, L., Yamagishi, H., Marui, H., and Kanno, T. (2005). Landslide in Sado Island of Japan: Part II. GIS-based susceptibility mapping with comparison of results from two methods and verifications. Eng Geol 81:432-445

Beaula, T., and Partheeban, J. (2013). Risk Assessment of Natural Hazards in Nagapattinam District using fuzzy logic model. International Journal of Fuzzy Logic Systems (IJFLS) Vol.3, No3, July 2013

Blair, A. N., Ayyub, B. M., and Bender, W.J. (2001). Fuzzy stochastic risk based decision analysis with the mobile offshore base as a case study. Marine Structures 14, 69-88.

Dai, F. C., Lee, C. F., and Nagi, Y. Y. (2002). Landslide risk assessment and management: an over view. Engineering Geology: 64, 65- 87.

Darbra R.M., and Casal J. (2009). Environmental risk assessment of accidental releases in chemical plants through fuzzy logic, Chemical Engineering Transactions 17, 287-292.

Eker, R., and Aydin, A. (2014). Assessment of the forest road conditions in terms of landslide susceptibility: A case study in Yığılca Forest Directorate (Turkey). Turkish Journal of Agriculture and Forestry 38(2): 281-290, doi: 10.3906/tar-130312.

Ercanoğlu, M, and Gökceoğlu, C. (2002). Assessment of landslide susceptibility for a landslide-prone area (north of Yenice, NW Turkey) by fuzzy approach. Environ Geol 41: 720730.

Ercanoglu, M., and Temiz, F. A. (2011). Application of logistic regression and fuzzy operators to landslide susceptibility assessment in Azdavay (Kastamonu, Turkey). Environmental Earth Science 64: 949-964, doi: 10.1007/s12665-011-0912-4.

Gjerdrum, D., and Peter, M. (2011). The new international standard on the practice of risk management - A comparison of ISO 31000:2009 and the COSO ERM framework. Risk management, Issue 21, 8-12.

Gorsevksi, V., Jankowski, P., and Gessler, P.E. (2006). An heuristic approach for mapping landslide hazard by integrating fuzzy logic with analytic hierarchy process. Control and Cybernetics 35(1): 121-146.

Huppert, H. E., and Sparks, R. S. J. (2006). Extreme natural hazards. Philosophical Transactions of the Royal Society 364: 1875-1888.
Jang, J.S.R. (1993). ANFIS: adaptive-network-based fuzzy inference system. IEEE Journal 23(3): 665-685, doi: $10.1109 / 21.256541$

Karimpour, K., Zarghami, R., Moosavian, M.A., and Bahmanyar, H. (2016). New Fuzzy Model for Risk Assessment Based on Different Types of Consequences. Oil \& Gas Science and Technology - Rev. IFP Energies nouvelles (2016) 71, 17.

Melching, C., and Pilon, P. (2006). Comprehensive Risk Assessment for Natural Hazards. The World Meteorological Organization Press.

Osna, T., Sezer, E.A., and Akgün, A. (2014). GeoFIS: An integrated tool for the assessment of landslide susceptibility, 66: 20-30, doi:10.1016/j.cageo.2013.12.016.

Pokoradi, L. (2009). Risk assessment based upon fuzzy set theory. In: 15 ' th Building Services, Mechanical and Building Industry Days, Debrecen, Hungary. pp. 311-318.

Pourghasemi, H.R., Pradhan, B., and Gökçeoğlu, C. (2012). Application of fuzzy logic and analytical hierarchy process (AHP) to landslide susceptibility mapping at Haraz watershed, Iran. 63(2): 965-996, doi: 10.1007/s11069-012-0217-2.

Pradhan, B. (2010). Landslide Susceptibility mapping of a catchment area using frequency ratio, fuzzy logic and multivariate logistic regression approaches. J. Indian Soc. Remote Sens. 38: 301- 320, doi: 10.1007/s12524-010-0020-z.

Puecker T. K. (1978). "Data Structures for Digital Terrain Models: Discussion and Comparison", ht..lIl1 Myanced Stucly Symposjum OD Topological Data Structures for Geographical Information SystemsHarvard Paper on Geographical Information Systems, Edited by G.Dutton, Vol. 5

Puequet, D. J. (1990). "A Conceptual Framework and Comparison of Spatial Data Models", In; Introductox:y Readings in Geographical Information Systems,Edited by D.J.Peuquet and D.F.Marble, Taylor \& Francis Publication, pp. 250-285.

Shang, K., and Hossen, Z. (2013). Applying Fuzzy Logic to Risk Assessment and Decision-Making, North America: CAS/CIA/SOA Joint Risk Management Section.

Tahirkheli, R. A. K., and Jan, M. Q. (1979). Geology of Kohistan, Karakoram Himalaya, northern Pakistan. University of Peshawar Geological Bulletin Special Issue, 13, 1-187.

Tangestani, M. H. (2009). A comparative study of DempsterShafer and fuzzy models for landslide susceptibility mapping using a GIS: An experience from Zagros Mountains, SW Iran. Journal of Asian Earth Sciences 35: 66-73, doi:10.1016/j.jseaes.2009.01.002.

Vahidnia, M. H., Alesheikh, A. A., Alimohammadi, A., and Hosseinali, F. (2010). A GIS-based neuro-fuzzy procedure for integrating knowledge and data in landslide susceptibility mapping. Computer and Geoscience: 36, 1101-1114.

Yanar, T. A., and Akyürek, Z. (2006). The enhancement of the cell-based GIS analyses with fuzzy processing capabilities. Information Sciences 176: 1067-1085, doi:10.1016/j.ins.2005.02.006. 
Yazdi. J., and Salehi, S. A. A. (2012). Optimal design of floodcontrol multi-reservoir system on a watershed scale. Nat. Hazards. v63 i2. 629-646.

Yin, A., and Harrison, T. M. (2000). Geologic Evolution of the Himalayan Tibetan Orogen. Journal of Earth Planetr Sciences, 28, 211-80.

Yin., A., (2006). Cenozoic tectonic evolution of the Himalayan orogen as constrained by along-strike variation of structural geometry, exhumation history, and foreland sedimentation, Earth-Sci. Rev. 76, 2006 1-131.

Zadeh, L. A. (2008). "Is there a need for fuzzy logic", Information Sciences 178(13), 2751-277.

Zlateva P., Gerginova M., Manasiev J., Atanasov B., Peneva N., Dimova N., and Alexieva Z. (2005), Kinetic parameters determination of the phenolic derivatives assimilation by Trichosporon cutaneum R57. Biotechnol. Biotechnol. Eq. 19, 93Đ97.

Zlateva P., Pashova L., Stoyanov K., Velev D. (2011) Fuzzy Logic Model for Natural Risk Assessment in SW Bulgaria. 2nd International Conference on Education and Management Technology IPEDR, 13, IACSIT Press, Singapore. 